\title{
CIRCULAR PRIORITY SYSTEMS
}

\section{GRANT GILMORE $\dagger$}

What should be done when an inadequate fund is to be distributed among competing claimants and under applicable rules of law, $A$ is entitled to priority over $B$, who is entitled to priority over $C$, who is entitled to priority over $A$ ? Or, in a variant, when $B$ and $C$ have claims entitled to equal priority, one of which is superior, the other inferior, to $A$ 's claim? The problem has long entertained lawyers, particularly those in whom a speculative turn of mind is allied with some proficiency in mathematics. ${ }^{1}$ Several exceedingly complex all-purpose theoretical solutions have been proposed. These have been ignored by the courts. A judge who finds himself face to face with a circular priority system typically reacts in the manner of a bull who has been goaded by the picadors: he paws the ground and roars with rage. The spectator can only sympathize with judge and bull.

In the most comprehensive contribution to the literature on circular priorities $^{2}$ it has been suggested that there are three quite different types of situation out of which circular, or apparently circular, systems may arise and that quite different solutions are appropriate to the several situations. Confusion, which is unavoidable at best, is compounded when the three basic situations are not clearly distinguished.

The simplest of the three situations, which may be dismissed as not involving a "true circularity," arises from a contractual subordination or waiver.

tWilliam K. Townsend Professor of Law, Yale Law School.

I am much indebted to Barbara Deutsch, Esq., of the Connecticut bar and to the editors of the Law Journal for their help in preparing this article for publication. The article is taken from a chapter on the general subject of priorities in a forthcoming treatise on the law of personal property security transactions, to be published by Little-Brown \& Co.

1. The basic literature on circular priorities includes Benson, Circularity of Lien-A Problcm in Priorities, 19 MInN. L. Rev. 139 (1935) ; Campbell, Protection Against Indirect Attack, in Harvard Legar Essays 3 (1934); Kocourek, A First Rate Legal Puzzle -A Problen in Priorities, 29 IzL. L. Rev. 952 (1935); Moon, "The Deeds of Trust Puszle"-A Reply, 1 VA. L. Reg. 254 (1895); Tucker, The Deeds of Trust Puzzle: A Legal Paradox, 1 VA. L. Reg. 4 (1895); Note, Circuity of Priorities and Liens umder Section 67(c)(1) of the Bankruptcy Act, 66 YaLE L.J. 784 (1957); Note, Circuity of Lien -A Proposed Solution, 38 Colum. L. Rev. 1267 (1938); Note, The Three Cornered Prioritics Puzzle, 8 VA. L. Rev. 550 (1922).

Other references, of lesser merit or of an incidental nature, are Note, Priorities Puzzle under Ship Mortgage Act, 2 WAsH. L. Rev. 117 (1927); Peck, Federal Tax Liens-Their Removal ar Foreclosure, Privity Thereof, and the Problem of Circuity of Priorities, 38 Neb. L. Rev. 163, 170 (1959); White, A Problem in Priorities, 25 OHIo I. REP. 116 (1926) ; Comment, Priorities Between Mortgages and Mechanics Liens, 36 Y ALE L.J. 129 (1926) ; Note, 67 Harv. L. Rev. 358 (1953); Note, 15 VA. L. Rev. 90 (1928).

There is an excellent summary of the literature in OsBorN, MORTGages $\$ 209$ (1951); a less complete summary appears in 4 Collier, BANKRuptcy $\$ 67.27$ (3) (14th ed. 1954).

2. Note, 38 ColuMr. L. REv. 1267 (1938). 
To start with, $A, B$, and $C$ have claims against debtor $X$ or his property which are entitled to priority in alphabetical order: the classical example is that of first, second and third mortgages on Blackacre. $A$ subordinates his claim to $C$ 's. Blackacre is sold and the resulting fund is insufficient to satisfy all three claims. There is a comforting unanimity, among courts and commentators, on the proper distribution of the fund $:^{3}$

1. Set aside from the fund the amount of $A$ 's claim.

2. Pay the amount so set aside to

a) $C$, to the amount of his claim;

b) $A$, to the extent of any balance remaining after $C$ 's claim is satisfied.

3. Pay $B$ the amount of the fund remaining after $A$ 's claim has been set aside.

4. If any balance remains in the fund after $A$ 's claim has been set aside and $B$ 's claim has been satisfied, distribute the balance to

a) $C$,

b) $A .4$

Thus $C$, by virtue of the subordination agreement, is paid first, but only to the amount of $A$ 's claim, to which $B$ was in any event junior. $B$ receives what he had expected to receive: the fund less $A$ 's prior claim. If $A$ 's claim is smaller than $C$ 's, $C$ will collect the balance of his claim, in his own right, only after $B$ has been paid in full. $A$, the subordinator, receives nothing until $B$ and $C$ have been paid except to the extent that his claim, entitled to first priority, exceeds the amount of $C$ 's claim which, under his agreement, is to be first paid.

The second situation arises from the operation of any filing (or recording) system which provides that a failure to file subordinates the unfiled interest to subsequent interests which are not chargeable with knowledge of the unfiled interest but leaves the unfiled interest with priority over subsequent interests which are chargeable with such knowledge. ${ }^{5}$ Most filing systems are of this type, so that the possibility of a circularity of priorities is omnipresent. The traditional example is put in terms of successive mortgages. $A$ takes a first mortgage, which he fails to file. $B$ takes a second mortgage, with notice of the mortgage to $A$, and files. $C$ takes a third mortgage, without notice of the mortgage to $A$. $A$ has priority over $B$ (because of $B$ 's knowledge); $B$ has

3. Wayne Int'l Bldg. \& Loan Ass'n v. Moats, 149 Ind. 123, 48 N.E. 795 (1897); Fidelity Union Title \& Mortgage Guar. Co. v. Magnifico, 106 N.J. Eq. 559, 151 Atl. 499 (Ch. 1930) ; Malmgren v. Phinney, 50 Minn. 457, 52 N.W. 915 (1892).

4. For a recent case in which such a distribution was ordered (although the circularity did not arise from a contractual subordination), see In re American Zyloptic Co., 181 F. Supp. 77 (E.D.N.Y. 1960), discussed in the text accompanying notes 57-61 infra.

5. This is, of course, the pattern under most recording statutes, though a few states give priority to the party who first records without regard to his knowledge of a prior unrecorded document. See 4 Amserican LaW of Property \& 17.9 (Casner ed. 1952). An occasional chattel mortgage act makes a mortgage "void" unless filed within a specified period after execution; see, e.g., Ilz. Rev. Stat. ch. 95 \& 4 (1957). 
priority over $C$ (because of prior filing); $C$ has priority over $A$ (because of $A$ 's failure to file and $C$ 's lack of knowledge). In this situation, the circularity arises because of $A$ 's failure to file: on a theory of fault $A$ seems to be the appropriate person to penalize. ${ }^{6}$

In the third situation, however, none of the parties who are caught in the revolving door is in any way at fault and the circularity arises because, by statute or judicial decision, inconsistent rules of priority have been established for different interests. Two instances of this type of circularity have become familiar in recent litigation.

One arises from the statutory priority to which the United States is entitled for tax liens perfected under sections 6321-6323 of the Internal Revenue Code ${ }^{7}$ or for the payment of any debts owed it by an insolvent under section 3466 of the Revised Statutes. ${ }^{8}$ In a long series of decisions the United States Supreme Court has established the doctrine that such claims of the United States have priority over various types of antecedent interests which are in some sense "inchoate": under this doctrine, state, county and municipal tax claims have often been subordinated to subsequent claims of the United States. ${ }^{9}$ However, the claims thus subordinated by federal law are typically by state law entitled to priority over antecedent or subsequent security interests. The security interests, although subordinated to the local tax claims, continue (or so it may be assumed for the purpose of our present discussion $)^{10}$ to enjoy priority over subsequently accruing or perfected claims of the

6. A few old cases suggest an added situation in which $A$ is "at fault" through failure to levy execution on a first judgment, thereby losing his priority as to subsequent executed judgments, but not as to intermediate mortgages which in turn take priority over the subsequent judgments. See, e.g., Meeker v. Warren, 66 N.J. Eq. 146, 57 Atl. 421 (Ch. 1904); Andrus v. Burke, 61 N.J. Eq. 297, 48 Atl. 228 (Ch. 1901). See also Donnelly v. Lulfs, 12 Ohio App. 305 (1918) (aberrational situation where the debtor's statutory exemption took priority over a judgment which was prior to a chattel mortgage which took priority over the exemption; the subordination rule of distribution was applied).

7. INT. Rev. CoDE of 1954, $\$ \S 6321-23$ (formerly Int. Rev. Code of 1939, $\$ \$ 3670-72$ ).

8. 1 Stat. 515 (1797), 31 U.S.C. $\$ 191$ (1958).

9. Tax lien: United States v. R.F. Ball Constr. Co., 355 U.S. 587 (1958); United States v. White Bear Brewing Co., 350 U.S. 1010 (1956); United States v. Scovil, 348 U.S. $21 S$ (1955) ; United States v. Liverpool \& London \& Globe Ins. Co., 348 U.S. 215 (1955) ; United States v. City of New Britain, 347 U.S. 81 (1954) ; United States v. Security Trust \& Sav. Bank, 340 U.S. 47 (1950).

Section 3466 priority: United States v. Gilbert Associates, 345 U.S. 361 (1953) ; Illinois c.x rel. Gordon v. Campbell, 329 U.S. 362 (1946) ; United States v. Waddill, Holland \& Flinn, Inc., 323 U.S. 353 (1945) ; United States v. Texas, 314 U.S. 480 (1941); United States v. Knott, 298 U.S. 544 (1936); New York v. Maclay, 288 U.S. 290 (1933).

See generally Kennedy, The Relative Priority of the Federal Government: The Pernicious Carecr of the Inchoate and General Lien, 63 YALE L.J. 905 (1954); Plumb, Fedcral Tax Collection and Lien Problems, 13 TAX L. REv. 247, 459 (1958). The recent law review literature approaches infinity.

10. The case of United States v. R. F. Ball Constr. Co., 355 U.S. 587 (1958), has generated a certain amount of ambiguity as to the continuing truth of this proposition. See Myers, The Fall and Rise of the Security Interest, Prac. Law., Dec. 1960, p. 60; Note, 43 Minn. L. Rev. 755 (1959). 
United States. Thus the city may by state law have priority for its tax claim over a mortgagee who has priority over the United States (by federal law), which has priority over the city (also by federal law).11

The second instance results from provisions of the Federal Bankruptcy Act. Section 67 (c) (1) ${ }^{12}$ provides that certain "statutory liens ... on personal property not accompanied by possession of such property, and liens, whether statutory or not, of distress for rent shall be postponed in payment to the debts specified in [section 64(a)(1) and (2)]."13 Section 64 establishes priorities of payment in a bankruptcy liquidation for various types of unsecured claims: clauses (a) (1) and (a) (2) give such priority to the expenses of bankruptcy administration and to certain wage claims. Thus, the administration expenses and wage claims have priority over the statutory liens and landlord's liens; these liens frequently, by state law, have priority over consensual security interests; the security interests, if perfected, have priority over the unsecured administration expenses and wage claims.

There has never been agreement on the correct solution of circular systems which arise either from the failure of one party to make a required filing or from inconsistent rules of priority. Indeed, while the distinction between these two types of circularity has been urged by commentators, it has been ignored by the courts, which have in general lumped the two types together. Most of the older cases involved the circularity which arises from a failure to file; the focus of recent litigation has been the circularity created by conflicting bodies of state and federal law. ${ }^{14}$

In a considerable number of cases the courts have applied to circularities of the two types just described the rule of distribution which, as stated earlier, everyone seems to find appropriate in cases of apparent circularity by subordination: that is, once the parties have been tagged $A, B$, and $C$, set aside the amount of $A$ 's claim; from that amount pay $C$ first and then $A$ if anything is left; pay $B$ first from the balance after $A$ 's claim is set aside; and so on..$^{15}$ The question arises why the subordination rule is not a sensible solution

11. See cases cited at note 9 supra.

12. 30 Stat. 564 (1898), as amended, 11 U.S.C. $\$ 107$ (c) (1) (1958).

13. 30 Stat. 563 (1898), as amended, 11 U.S.C. $\$ \$ 104(\mathrm{a})(1),(2)$ (1958).

The statutory liens referred to in $\S 67$ (c) (1) are described in $\S 67(\mathrm{~b})$ as "statutory liens in favor of employees, contractors, mechanics, landlords, or other classes of persons, and statutory liens for taxes and debts owing to the United States or to any State or any subdivision thereof. .." 30 Stat. 569 (1898), as amended, 11 U.S.C. $\$ 107$ (b) (1958). The term "statutory lien" does not include consensual security interests. See 4 Collrer, BankRUPTCY $\$ 67.20$ (2) (14th ed. 1954). Many of the liens "postponed" by $\S 67(c)(1)$ are invalidated, as to a trustee in bankruptcy, by $\$ 67(\mathrm{c})(2)$; as to the liens which are postponed by $\S 67(\mathrm{c})(1)$ but not invalidated by $\$ 67$ (c) (2), see id. at $\$ 67.281$.

14. See notes $9 \& 12$ supra and accompanying text.

15. See Exchange Bank \& Trust Co. v. Tubbs Mfg. Co., 246 F.2d 141 (5th Cir.), cert. denied, 355 U.S. 868 (1957) (conflicting federal-state priority systems); California State Dep't of Employment v. United States, 210 F.2d 242 (9th Cir. 1954) (bankruptcy circularity); United States v. Lord, 155 F. Supp. 105 (D. N.H. 1957) (conflicting federal- 
in the "true" circularity cases. It has often been asserted, with some heat, that the subordination cases and the true circularity cases are "quite distinct" and require different rules of distribution $;^{16}$ the distinction is clear enough but why it should make a difference is much less so. Insofar as the argument for different rules has been articulated, it seems to rest on the thought that the application of the subordination rule in true circularity cases gives $C$ a windfall at $A$ 's expense: it is one thing to give $C$ a priority he has bargained, and presumably paid, for and quite a different thing to give him an unanticipated advantage by reason of the existence of a prior claim which, by hypothesis, $C$ knew nothing about. This argumentation has appeared more convincing to commentators than to courts. We may defer our own conclusions on its merits until we have reviewed the various alternative solutions which have been proposed on the assumption that the subordination rule should not be applied to true circularity cases.

Some courts have merely broken the circle and realigned the parties in a new order of priority.

One method of doing this, which has been called the Pennsylvania method, is to revert to the "normal" rule that "first in time is first in right" and distribute the fund to the competing claimants in the chronological order in which their claims accrued. ${ }^{17}$ This rule, which evolved from cases in which the circularity was caused by $A$ 's failure to file, simply ignores the fact that $A$ 's unfiled mortgage has, according to the filing statute, become "void" as to $C$ (who, by hypothesis, comes in without knowledge of $A$ ).

A second method, which has been called the New Jersey method, distributes the fund first to $B$, then to $C$, then to $A .{ }^{18}$ This rule also evolved from

state priority systems); In re Empire Granite Co., 42 F. Supp. 450 (M.D. Ga. 1942) (bankruptcy circularity) ; Brown v. General Laundry Ser., 19 Conn. Supp. 335, 113 A.2d 601 (Super. Ct. 1955) (conflicting federal-state priority systems); Samms v. Chicago Title \& Trust Co., 349 Ill. App. 413, 111 N.E.2d 172 (1953) (conflicting federal-state priority systems) ; Manchester Fed. Sav. \& Loan Ass'n v. Emery-Waterhouse Co., 102 N.H. 233, 153 A.2d 918 (1959) (conflicting federal-state priority systems) ; Southern Ohio Sav. Bank \& Trust Co. v. Bolce, 165 Ohio St. 201, 135 N.E.2d 382 (1956) (conflicting federal-state priority systems). See also cases cited at notes 51,56 \& 59 infra.

But sec cases where the courts have resolved the problem by breaking the circle and forming a new order of priority: In re Einhorn Bros., Inc., 272 F.2d 434 (3d Cir. 1959) (bankruptcy circularity) ; In re Quaker City Uniform Co., 238 F.2d 155 (3d Cir. 1956) (bankruptcy circularity); In re Ann Arbor Brewing Co., 110 F. Supp. 111 (E.D. Mich. 1951) (bankruptcy circularity); City of New Orleans v. Harrell, 134 F.2d 399 (5th Cir. 1943) (bankruptcy circularity); Ferris v. Chic-Mint Gum Co., 14 Del. Ch. 232, 124 Atl. 577 (Ch. 1924) (federal-state conflict of priority systems).

16. See Note, 38 Colum. L. Rev. 1267, 1269 (1938). Professor Benson gives the fullest explanation for the differentiation between subordination and true circularity cases. Benson, Circuity of Licn-A Problem in Priorities, 19 MINN. L. REv. 139, 143-44 (1938).

17. Benson, supra note 16 , at $141 \mathrm{n} .3$ cites the following cases as establishing the rule: Wilcocks v. Waln, 10 Serg. \& R. (Pa.) 380 (1824) ; Manufacturers' \& Mechanics' Bank v. Bank of Pennsylvania, 7 Watts \& S. (Pa.) 335 (1844); Thomas' Appeal, 69 Pa. St. 120 (1871) ; Miller's Appeal, 122 Pa. St. 95, 15 Atl. 672 (1888).

18. Benson, supra note 16 , at 142. 
cases in which $A$ 's failure to file caused the circularity. $\mathrm{He}$ is penalized by being put last. This rule ignores the fact that $A$ was entitled to priority over $B$ (who, by hypothesis, had knowledge of $A$ and was therefore subordinate to him). The $B-C-A$ rule of distribution seems to have had a greater following than the Pennsylvania $A-B-C$ rule. ${ }^{19}$

When a more satisfactory solution than merely breaking the circle at some point is sought, the starting point of discussion is always the formula proposed by Judge Dixon, dissenting in the New Jersey case of Hoag v. Sayre. ${ }^{20}$ The case involved successive mortgages to Hoag and Fisher and a judgment lien held by Sayre. The Hoag mortgage, although unfiled, had priority over the Fisher mortgage (Fisher having had knowledge), but, because of the lack of filing, was "void" as to Sayre's judgment lien. Fisher and Sayre were "concurrent" - that is, entitled to equal priority. Twelve judges held that distribution should be made according to what we have called the subordination rule: Sayre $(C)$ to be paid first, to the amount of Hoag's (A's) claim; Sayre $(C)$ and Fisher $(B)$, being concurrent, to share the balance pro rata. Dixon, the sole dissenter, offered alternative solutions, both for the instant case where $B$ and $C$ were concurrent and for the more usual case where $B$ has priority over $C$. In the usual case ( $A$ has priority over $B, B$ over $C$, and $C$ over $A$ ) distribution, he said, should be made as follows:

1. Pay $C$ the amount of the fund less $B$ 's claim.

2. Pay $B$ the amount of the fund less $A$ 's claim.

3. Pay the residue, if any, to $A$.

Since, in Hoag v. Sayre, $B$ and $C$ were concurrent, the first step in the formula should be varied as follows: Divide the fund "in the proportion of $B$ 's and $C$ 's claims and give to $C$ his proportion." Dixon's formula is, in sum, to treat both $B$ and $C$ as junior lienors : each gets what might be called his reasonable expectation as of the time his claim accrued-the fund less the claim which he knew, or ought, by constructive notice, to have known, was prior to his own. Dixon does not explain why the balance of the fund, after the junior lien claims have been deducted, should go to $A$.

In a trio of articles on circular priorities which appeared during the 1930's ${ }^{21}$ Dixon's formula was highly praised: "This formula must be regarded," said Professor Kocourek, "as a construct of formidable ingenuity, of great subtility, and of remarkable esthetic beauty."22 Nevertheless, the three theoreticians sadly concluded, the Dixon formula, for all its brilliance, was inadequate and imperfect.

Its principal defect was this: on various assumptions as to the amounts of

19. "Perhaps most fashionable." Note, 38 CoLUx. L. REv. 1267, 1269 (1938).

20. 33 N.J. Eq. 552 (1881).

21. Benson, Circuity of Lien-A Problem in Priorities, 19 Mrnn. L. Rev. 139 (1935); Note, 38 Colum. L. Rev. 1267 (1938) ; Kocourek, A First-Rate Legal Puzzle-A Problem in Priorities, 29 ILL. L. REv. 952 (1935).

22. Kocourek, supra note 21 , at 954 . 
the competing claims, $A$ (who, in the failure to file type of case, is the person at fault) takes the entire fund when the fund ranges from 0 to an amount we may call $X$; thereafter, as the fund increases beyond $X, A$ 's share decreases toward 0 ; when that point has been reached $A$ receives nothing until $B$ and $C$ have been paid in full. ${ }^{23}$ To the theoreticians it seemed wrong that $A$ (assumed to be the person at fault) should take the entire fund at points when $B$ and $C$ received nothing and anomalous that as the fund increased $A$ 's share should decrease. The authors of the three articles referred to set about to refine the Dixon formula to obviate these defects. Each proposed his own, slightly different, formula : we may call them the Benson formula, the Kocourek formula and the Columbia formula.

Professor Benson's formula treats each of the claimants in turn as a junior lienholder (instead of, as under the Dixon formula, giving $A$ the residue after determining $B$ 's and $C$ 's junior lienholder claims). His basic proposition was : "Each and every claimant is entitled to have applied to the payment of his claim the part of the fund remaining after an amount equal to the sum of the claims prior to his has been set aside." 24 This process can lead to four possible situations : the sum of the junior lien claims will be 1) $0 ;^{25}$ 2) less than the fund; 3 ) equal to the fund; 4) greater than the fund. In the first case, Professor Benson, despairing of logic, proposed that the fund be divided evenly among the claimants. In the second case, each should receive his junior lien claim and the balance be divided evenly among them. In the third case, the distribution according to the junior lien claims exhausts the fund. In the fourth case, he proposed an exceedingly complicated solution: determine the amount at which the junior lien claims would equal the fund; distribute that amount as in a class 3 case; divide the excess (in most cases) evenly among the claimants. ${ }^{26}$

23. Neither $B$ nor $C$ receives anything as a junior lienor until the fund exceeds the claim which is senior to his. Thus $A$, who, under the Dixon formula, takes the residue, is the winner until the fund exceeds one or both of the claims; as the fund increases, the junior lien claims grow larger and $A$ 's claim shrinks until it reaches zero at the point when the junior lien claims equal the fund. The following table illustrates the process: assume that each of the claimants has a claim of 4 .

\begin{tabular}{crrrrrrrrrrrr}
\hline Amount of fund: & 1 & 2 & 3 & 4 & 5 & 6 & 7 & 8 & 9 & 10 & 11 & 12 \\
A & 1 & 2 & 3 & 4 & 3 & 2 & 1 & 0 & 1 & 2 & 3 & 4 \\
B & 0 & 0 & 0 & 0 & 1 & 2 & 3 & 4 & 4 & 4 & 4 & 4 \\
C & 0 & 0 & 0 & 0 & 1 & 2 & 3 & 4 & 4 & 4 & 4 & 4 \\
\hline
\end{tabular}

24. Benson, supra note 21 , at 147 (italics removed).

25. The junior lien claims will equal 0 when each is junior to a senior claim which is greater than the fund : for example, the fund is $2 ; A, B$ and $C$ each has a claim of 3 .

26. Professor Benson demonstrates that the fund increases from class to class. Thus the class 4 fund (sum of the junior lien claims exceeds the fund) will necessarily be larger than the class 3 fund (sum of the junior lien claims equals the fund). He suggests that determination of the amount or amounts at which the sum of the claims would equal the fund must be made by a trial and error process, but that in almost every case that amount "is either an amount equal to one-half the sum of the claims or an amount equal to one of the sums of the prior claims." Benson, supra note 21, at 155. 
Professor Kocourek objected, with reason, that the Benson formula "could not be applied with success administratively" and that "Masters, chancellors and appellate judges would find themselves in an intellectual bellum internecinum" in its application.27 Aiming at simplicity Professor Kocourek proposed the following formula: "Deduct from the fund the amount of $B$ 's claim and apply the remainder (if any) to $C$ 's claim, and then after subtracting from $A$ 's claim the amount (if any) allocated to $C$, apply as follows: 1) $A$; 2) $B$; 3) $A$. "28 That is, $C$ is first paid his junior lien claim (as under both the Dixon and Benson formulas) ; then $A$ is paid from the balance his claim less whatever has been paid to $C$; if anything is left, $B$ is paid; if $A$ has not been paid in full on his first participation, he takes the balance, after $B$ has been paid in full, to the extent of the deficiency; $C$ apparently gets only his junior lien claim (the amount of which depends on the relationship between $B$ 's senior claim and the amount of the fund) until both $A$ and $B$ have been paid in full. His formula, Professor Kocourek noted, was subject to the same infirmity as the Dixon formula in cases where the claims are equal and the fund is less than or equal to the amount of any of the claims: that is, $A$ (the hypothetical villian) takes the whole fund. ${ }^{29}$ To avoid the infirmity, Professor Kocourek suggested that, as an exception to the general formula, the fund in such cases might as well be divided evenly-just as Professor Benson had suggested an equal division in the comparable case where no claimant has a claim as junior lienor. Professor Kocourek, however, went one step further in his analysis: if the fund is to be divided evenly in cases where application of the formula will give $A$ the entire fund before $B$ or $C$ has received anything, it will be to $A$ 's advantage in a foreclosure sale to bid the mortgaged property in at a price just over the amount at which the formula is to be discarded: at that point $C$ 's junior lien claim is still so small that $A$ will profit by driving up the price. ${ }^{30}$ To save $A$ from this temptation, Professor Kocourek's proposal was that the fund be equally divided until it reached the point where $A$ would no longer profit from raising the ante. ${ }^{31}$

27. Kocourek, supra note 21, at 953.

28. $I d$. at 955 (italics removed).

29. The Kocourek formula suffers from this disability over a somewhat broader range than Professor Kocourek suggested: $A$ takes the fund whenever $B$ 's claim equals or exceeds the fund, since in that case $C$ has no junior lien claim and $A$ is paid in full before $B$ (or $C$ ) gets anything.

30. For example (to use Professor Kocourek's illustration in which all the claims are equal), if the fund (i.e. the "true value" of the property) is 5 and each claim is 5 , then if the fund is divided evenly, each receives $12 / 3$. If, however, $A$ buys the property for 6 , he receives 4 in distribution, while $B$ and $C$ each receive 1 . On the equal division, $A$ 's net loss is $3 \mathrm{x} / 3$. On the artificial bid of 6 , his net loss is 2 (i.e. his claim of 5 plus his bid of 6 less the distribution payment (4) less the assumed value of the property (5).

31. Using the same figures as in the preceding illustration, Professor Kocourek suggests that this point would be reached when the fund was $6 \% 3$ (i.e. the actual fund plus $A$ 's distributive share if it were divided evenly). That is, if the fund is not divided evenly and $A$ bids it in at $62 / 3$, his net loss will be $3 \frac{\pi}{3}$ ( 5 (claim) $+62 / 3$ (bid) $-3 \frac{1}{3}$ (distributive share) -5 (assumed value of property) $=3 \mathrm{I} / 3$ ), which is the same as his net loss on an equal division when the property is sold for its true value of 5 . 
Professor Kocourek's analysis of the temptation to overbid is correct as far as it goes but should be carried a step farther: because of the fact that $A$ 's distributive share shrinks as the junior lien claims increase (this is true under all the formulae), $B$ and $C$ (acting singly or in collusion) may be in a position to reduce their net losses by driving the price up even higher, to the point where $A$ 's share is $0 .{ }^{32}$ Thus, on the assumption that $A, B$ and $C$ are all mathematicians, it is pointless to protect $B$ and $C$ from $A$ 's overbid; it is $A$ who should be protected against even more inflated overbids by $B$ and $C$, which take advantage of the shrinkage to which the junior lien formulae subject $A$ 's share.

Professor Kocourek's general formula might be described as a hybrid of the Dixon formula (pay $C$ as junior lienor) and the subordination rule (pay $A$ in priority to $B$ the amount of his claim less what goes to $C$ ) plus the equal division exception to cure the infirmity that $A$ takes the entire fund when it is less than $B$ 's claim. The Kocourek formula is simpler to apply than the Benson formula, but it does not appear to be a great deal easier to understand.

The most comprehensive of the three attempts to provide a theoretical solution of the problem is the Columbia formula..$^{33}$ The authors of this formula accepted as a starting point the desirability of working out a solution in terms of treating each party as a junior lienor but set themselves the task of avoiding either the result of $A$ 's taking the entire fund at any point or the result of $A$ 's share shrinking as the fund increases. Any formula under which $A$ 's share shrinks, they pointed out, encourages artificially high bids at a foreclosure sale by $B$ and $C$. For cases of true circularity (that is, where no party is at fault), they proposed the following solution: "Ascertain what the junior lienholders' claims would be if the fund were of such size that the sum of the junior lienholders' claims were equal to what the fund is in fact" and distribute the fund accordingly. ${ }^{34}$ No mathematical formula is offered for determination of the amount of the hypothetical fund which would produce junior lien claims whose sum would equal the fund which is actually available for distribution : if the process is one of trial and error, it would be a tedious one where

32. Continuing to use the same figures (fund 5 , each claim 5 ), if the fund were equally distributed at 5 , and $B$ and $C$ (acting in collusion) bid 10 , each would have a net loss (assuming they divided the property, worth 5 , between them) of $2 \frac{1}{2}$ (i.e., 5 (claim) +5 (share of bid) less 5 (distributive share) less $2 \frac{1}{2}$ (value of share of property), as compared with a loss of $3 \mathrm{I} / 3$ if the fund were evenly divided and a loss of 4 if they allowed $A$ to buy the property for 6 . If the fund were equally divided until it reached $62 / 3$ (at which point the distributive share would be $2 \%$, or a net loss of $2 \%$ ), it would still be profitable for $B$ and $C$ to bid up to 10 , thus reducing their net loss to $2 \frac{1}{2}$. Naturally $B$ and $C$ minimize their own losses at $A$ 's expense when the property goes for $10, A$ receives nothing as a distributive share and has a net loss of 5 (his entire claim).

This point is noticed in the Columbia Note proposing the formula which is described in the text beginning at note 33 infra.

33. Note, 38 Colur. L. REv. 1267 (1938).

34. Id. at 1274 . 
large sums are involved..$^{35}$ Accompanying graphs are designed to prove that, under the proposed formula, $A$ never takes the entire fund before $B$ and $C$ receive anything and that $A$ 's share does not shrink as the fund increases. An alternative solution is proposed for cases where the circularity results from the fault (typically, the failure to file) of one of the claimants: the authors remark, without further explanation, that the party at fault "must be treated as having no junior lienholder's claim, but as being entitled to the residue of the fund after the other parties have received their junior lienholders' claims." 36 This is Judge Dixon's original formula. However, the authors go a step further: they propose a method for determining a "minimal amount"

35. One of the editors of the Yale Law Journal has suggested a formula which might be derived from the discussion in the Columbia note. This formula is best explained by an example.

Assume $A$ is owed $2, B$ is owed 6 , and $C$ is owed 3 where the fund to be distributed equals 6 . The author of the Columbia note postulates that for any fund $(X)$, each will expect $X$ minus the amount owed the lienholder directly prior to him. Thus in our example $A$ expects $(X-3), B$ expects $(X-2)$ and $C$ expects $(X-6)$. We wish a hypothetical fund which will cause the sum of these expectations to equal 6 , the amount in fact available for distribution. Thus, the formula becomes:

$$
\begin{aligned}
6=(X-3)+ & (X-2)+(X-6), \\
& \text { or } \\
6= & 3 X-11
\end{aligned}
$$

Being purely mathematical, this formula may lead to results which are impossible in the actual fact situation. This might occur in either or both of two ways. One or more of the group might under the hypothetical expect:

a) a negative amount

b) an amount greater than what he is actually owed.

One can determine whether either result has occurred by solving for $X$ and substituting this number into the original formula.

To return to our example:

$$
\begin{aligned}
& \text { since } 6=3 X-11 \\
& X=17 / 3
\end{aligned} \quad \begin{aligned}
& \text { substituting: } \\
& A \text { would expect } 8 / 3=22 / 3 \\
& B \text { would expect } 11 / 3=32 / 3 \\
& C \text { would expect }-1 / 3
\end{aligned}
$$

If all these amounts had been possible figures, that would be the end of the problem and these amounts would be distributed. Unfortunately we see that both $A$ 's and $C$ 's expectations are impossible. A solution, however, may still be obtained. Since $C$ cannot expect less than 0 , we simply consider his expectation 0 and discard its algebraic representation $(X-6)$ from the formula. As $A$ can only expect 2, we take this as his expectation and remove $(X-3)$ from the formula. But since we have assigned part of the fund to $A$ this amount must be subtracted from the left side of the equation. Thus we have:

$$
\begin{gathered}
4=X-2 \\
X=6 \\
B \text { then expects } 4 \\
A \text { then expects } 2 \\
C \text { then expects } 0
\end{gathered}
$$

36. 38 Coluar. L. Rev. at 1275 . 
which $A$ (the party at fault) takes regardless of the size of the fund: if the fund does not exceed the minimal amount $A$ takes it all; he takes no more than that amount until $B$ and $C$ have been paid in full; beyond the minimal amount, $B$ and $C$ divide the fund as junior lienholders according to the formula used in cases of true (or no-fault) circularity. Since the present writer does not understand the process of arriving at the minimal amount to be paid $A$, the proposal will be set forth without comment in a footnote. ${ }^{37}$

None of the three formulae just described (or the four formulae, if Judge Dixon's original proposal is included) has ever been applied by any court in any case. The foregoing review will have demonstrated why this should be so. Two of them (the Benson and Columbia formulae) are exceedingly difficult to apply and it seems fair to say of all of them that the results they produce in the distribution of funds do not appear to be notable improvements over the results obtained by using a more simple-minded solution. The thought which underlies the idea of treating one (Kocourek) or two (Dixon) or all three (Benson, Columbia) of the claimants as junior lienors seems to be that this most nearly approximates the "reasonable expectations" which the several claimants had (or ought to have had) when they joined the cast of characters. At first glance this appears to be a plausible theory and would be a helpful one if its application led to an expeditious, understandable, and equitable distribution of the fund. The Dixon and Kocourek formulae are not difficult to apply but lead to some odd results. The attentive reader of the Benson article and the Columbia note is left with the impression that he has just witnessed the passage of three camels named $A, B$, and $C$ through the needle's eye. After these appalling complexities have been digested, one is tempted to wonder how closely the results achieved approximate the reasonable expectations of the parties or how sensible it is in any event to speculate about the reasonable expectation of parties trapped in so deviational a situation. Working out a solution of the circular priorities puzzle will continue to be an admirable parlor game. Having no solution of our own to propose, we shall return to a consideration of what the courts have in fact been doing in recent litigation.

37. First $A$ must get the amount below which his share as residual taker would not shrink no matter how large the fund. It is what $A$ would receive under Judge Dixon's formula if the fund were equal to $A$ 's claim plus $B$ 's claim. Then, as to the distribution of the remainder of the largest possible share that $A$ could get before $B$ and $C$ are completely satisfied, which causes the trouble since it decreases while the fund increases, there are three possibilities. He can take none, all or a part of it. Since we should deem the formula devised by Dixon, J., the ideal solution in this type of case, were it not for its impracticability, we reject the first two possibilities named as deviating from it more than the third. On the theory that each should be paid as nearly as possible in accordance with Judge Dixon's plan, $A$ should get twothirds of this amount, $B$ and $C$ each being deprived (albeit at different fund amounts) of one-third. If it is felt that $A$, being the guilty party, should bear somewhat more of the necessary sacrifice, i.e., if $A$ 's right to his "Dixon share" is felt to be less absolute than that of $B$ and $C$ to theirs, he should be given somewhat less-say oneId. at 1275 . half the amount. He would thus bear one-half the loss and $B$ and $C$ each one quarter. 
Since 1940 or thereabouts all the cases which have been discovered involve circularities which arise from contradictory systems of priorities established by state and federal law, either under section 67 (c)(1) of the Bankruptcy Act ${ }^{38}$ or under the Supreme Court's doctrine relating to the priority of federal tax liens and other federal claims. ${ }^{30}$ These are, then, cases of the type which have been called "true circularities"; the circularity arises by operation of law, none of the claimants being chargeable with fault. There is no reason, except the accident of litigation, for the disappearance from the reports of the type of case where the circularity arises from the fault of one party who has failed to make a filing which, if made, would have prevented the circularity from arising.

The most popular solution has been to apply the rule used in cases of apparent circularity resulting from a subordination agreement. ${ }^{40}$ In the subordination case $A, B$ and $C$ have liens which rank in that order: $A$ then subordinates his claim to C's. The solution is to set aside from the fund the amount of $A$ 's claim; pay that to $C$ and the balance, if any to $A$; pay $B$ from the remainder of the fund, the balance, if any, going to $C$ and $A$ in that order. In a true subordination case, it is assumed that there is no difficulty in establishing the normal order of priority which would have settled the distribution ( $A$ first, then $B$, then $C$ ) except for $A$ 's subordination to $C$. The real diffculty in applying the subordination rule to cases of true circularity is that there is no "normal" order to start from. We have, let us assume, a city tax lien, a federal tax lien and a mortgage as the competing claims. We may state the case thus: the city lien has priority over the mortgage, which has priority over the federal lien, which has priority over the city lien. Or thus : the mortgage has priority over the federal lien, which has priority etc. Or thus: the federal lien has priority over the city lien, which has priority etc. Which of the three claimants is $A$, which $B$, which $C$ ? Until we know, there is no way in which we can distribute the fund according to the subordination rule. As we shall see the courts appear to have been guided in making this crucial allocation more by instinct than by reason.

An odd sequence of cases seemingly underlies the recent popularity of the subordination rule. In Ferris v. Chic-Mint Gum Company ${ }^{41}$ the Delaware Court had to deal with local (i.e. state, county and municipal) tax and sewer liens, a mortgage and federal tax liens. By state law the local liens had priority over the mortgage. By federal law the federal liens (or some of them) had priority over the local liens but were subordinate to the mortgage. The Chancellor concluded that the local liens came first, the mortgage second and the federal liens last and should be paid in that order: "When the government agreed [under the tax lien statute] to take rank after the mortgagee, it must

38. See text beginning at note 12 supra.

39. See text beginning at note 7 supra.

40. See cases cited at note 15 supra and at notes 51,56 \& 59 infra.

41. 14 Del. Ch. 232, 124 Atl. 577 (Ch. 1924). 
necessarily follow that it is subordinate in rank to those who are superior to its immediate senior." 42 If the tax lien were given priority, "then indeed will the last be declared to be first." 43 The holding has nothing of interest; it is an illustration of how the circle can be broken by arbitrarily ignoring one of the relevant priorities. A few years later in Spokane County v. United States ${ }^{44}$ Chief Justice Taft, after saying that the Chic-Mint case was not in point since Spokane County did not involve a circular system, threw out the suggestion (which he attributed to government counsel) that "the relative priorities could have been maintained in [Chic-Mint] by setting apart sufficient funds to pay the mortgage before paying the federal taxes and then providing for payment of the state tax out of the sum so set apart." 45 That is, to translate the Chief Justice's suggestion into the alphabetical nomenclature we have been using in our hypothetical subordination case, the mortgage is $A$, the federal liens are $B$, and the local liens are $C$.

Chief Justice Taft's suggestion was picked up by Justice Schwartz writing for the Illinois Appellate Court in Samms v. Chicago Title \& Trust Company. ${ }^{40}$ In Samms, which was an action to foreclose a mortgage, the rival claimants were a mortgage, a mechanic's lien and a federal tax lien. Noting that the tax lien would have a "full and complete" priority over the mechanic's lien, if only those two claims were involved, Justice Schwartz concluded that the interposition of the mortgage, superior to the tax lien by federal law although subordinate to the mechanic's lien by state law, led to the result that "the Government . . . can only resort to those proceeds from the sale of the property which are in excess of the mortgage indebtedness. ... The mechanic's lien claimant by state law is given a lien prior to that of the mortgagee, which in effect means that it may resort to the proceeds from the sale of the property which are applicable to payment of the mortgage indebtedness." 47 The result, Justice Schwartz added, is "inevitable." Thus, the mortgage is $A$, the federal tax lien is $B$ and the mechanic's lien is $C$. The opinion does not give the amount of the fund or the amounts of the several claims; without going to the record, it is impossible to tell which claims were favored by the distribution which the Court ordered.48

42. Id. at 240,124 At1. at 580 .

43. Ibid.

44. 279 U.S. 80 (1929).

45. Id. at 91 .

46. 349 III. App. 413, 111 N.E.2d 172 (1953).

47. 349 IIl. App. at 422,111 N.E.2d at 176-77.

48. Chief Justice Taft's dictum in Spokane Connty as to how the priorities could have been "maintained" in the Chic-Mint case, was picked up by the Hawaii Federal District Court in Smith v. United States, 113 F. Supp. 702 (D. Hawaii 1953), decided at approximately the same time as the Samms case. (The Sanms and Smith opinions do not cite each other). Smith involved (among other claims) territorial liens, a mortgage, and federal liens. The court aligned the parties as the Illinois court had done in the Samms case: Mortgage $(A)$, federal lien $(B)$, territorial lien $(C)$, with the territorial lien to be paid out of the amount set aside for the mortgage. Chief Judge McLaughlin cites as having followed the Taft dictum, Hopkins v. Eureka Coal Co., 33 Am. Fed. Tax R. 1627 (1944). 
In Exchange Bank \& Trust Co. v. Tubbs Mfg. Co., ${ }^{49}$ the Fifth Circuit adopted the Illinois court's version of the subordination rule, with an approving reference by Judge Hutcheson to the "well reasoned opinion" in the Samms case. In Tubbs there were several chattel mortgages on the property of an insolvent corporation, city tax liens, and federal claims entitled to priority under section 3466 of the Revised Statutes. In a foreclosure action instituted by a mortgagee, a receiver had sold the insolvent's assets free of lien. The usual priority circle existed: by state law the city liens came ahead of the mortgages; by federal law the federal claim came ahead of the city liens but behind the mortgages. The Court ordered that judgment be entered "awarding priority to the respective mortgage claimants $[A]$, subject to payment of the city's taxes $[C], " 60$ balance to the United States $(B)$. Since the city's tax claims were small, the distribution was favorable to the mortgagees. ${ }^{51}$

A curious feature of the $T u b b s$ case is that Judge Hutcheson's opinion does not refer to the Fifth Circuit's own earlier decision in City of New Orleans v. Harrell. ${ }^{52}$ Harrell was a bankruptcy proceeding. The claims included chattel mortgages, a city tax lien, bankruptcy administration expenses, and wage claims. The city lien, it was argued, had priority over the mortgages by state law; the lien, however, under section 67 (c) (1) of the Bankruptcy Act, was subordinated to the administration expenses and wage claims, which, being unsecured, were subordinate to the mortgages. The bankruptcy referee ordered that the mortgages be paid first, then the administration expenses (entitled to first priority under section $64(\mathrm{a})(1)$ : These payments exhausted the fund, so that nothing was left for the wage claims or the city. On appeal this distribution was routinely affirmed. The distribution, it may be noted, is, in substance, the one which the Delaware court had ordered in the Chic-Mint case (which was not in bankruptcy) and definitely did not follow the subordination rule suggested by Taft in Spokane County, which the 1957 Tubbs case adopts. (If the fund in Harrell had been distributed according to the Tubbs rule, the

49. . 246 F.2d 141 (5th Cir.), cert. denied, 355 U.S. 868 (1957).

50. 246 F.2d at 144.

In Southern Ohio Sav. Bank \& Trust Co. v. Bolce, 165 Ohio St. 201, 135 N.E.2d 382 (1956), the Ohio Supreme Court, without citing any precedents on the method of distribution, came to the same conclusion: set aside the amount of the mortgage $(A)$; from this pay the state tax liens $(C)$; balance of the fund after the mortgage amount had been set aside to the federal tax lien $(B)$. See also United States v. Lord, $155 \mathrm{~F}$. Supp. 105 (D. N.H. 1957) ; Brown v. General Laundry Serv., Inc., 19 Conn. Supp. 335, 113 A.2d 601 (1955).

51. Another case which, by implication, reaches the same result as Samms and Tubbs is United States v. Bond, 172 F. Supp. 759 (E.D. Va. 1959). In Bond the mortgagee had paid local taxes which by state law would have been superior to the mortgagor. A federal lien was inferior to the mortgage but would have been superior to the local tax claim. Judge Bryan gave the mortgage priority over the federal lien for the original mortgage debt plus the subsequent payments of taxes. Judge Bryan relied partly on future advance theory and partly on the circularity cases, citing Tubbs, Samms, and the Smith case, supra note 48 .

52. 134 F.2d 399 (5th Cir. 1943). 
distribution would have been: pay the city $[C]$ out of the amount set aside for the mortgages $[A]$; balance to the section $64(\mathrm{a})$ priorities [B].) Judge Hutcheson had concurred specially in Harrell; his failure to discuss Harrell in Tubbs suggests that the Harrell type of circularity (created by the section 67 (c) (1) subordination) has nothing to do with the Tubbs type of circularity (created by the Supreme Court doctrine of federal priorities) and that different rules apply to the two types of cases. Or the failure to reconsider Harrell in the light of the $T u b b s$ facts may have been due merely to the inadvertence of counsel or court. At all events, the Harrell-Tubbs sequence leaves the present situation in the Fifth Circuit obscure.

A few years before the Tubbs case, the Ninth Circuit had found its way to a distribution according to the subordination rule in a section 67 (c) (1) case, California State Dep't of Employment v. United States. ${ }^{53}$ In the California case there were federal liens which, apart from the bankruptcy, were concededly superior to state liens. The federal liens were, however, subordinated by section 67 (c) (1) to bankruptcy administration expenses, while the state liens were not (the state had taken possession of the bankrupt's property and section 67 (c) (1) subordinates only nonpossessory liens). The court concluded that the administration expenses $(C)$ must be "satisfied out of the sum set aside for the Government claim [A]." ${ }^{\text {" }}$ As it happened, the federal liens exceeded the available fund, so that the State $(B)$ took nothing: the actual result was the same as if the court had ordered the administration expenses paid first, the federal liens second, and the state liens third. If the federal liens had been less than the fund, the state (as $B$ ) would, however, have received the balance in priority to the administration expenses. It will be noted that the California case puts the federal lien in $A$ 's slot, which in the ustal case is occupied by the mortgage while the federal lien is $B$ : we shall revert to this point somewhat later. The Ninth Circuit seems to have discovered the subordination rule without the aid of the Taft dictum in Spokane County or its elucidation in the Samms and Smith cases. Nor does Judge Orr's opinion refer to the Fifth Circuit's Harrell case. ${ }^{55}$ Evidently, however, the Ninth Circuit saw no reason why the subordination rule was not appropriate in a section $67(\mathrm{c})(1)$ case. ${ }^{66}$

53. 210 F.2d 242 (9th Cir. 1954).

54. Id. at 245 .

55. Judge Hutcheson's opinion in Tubbs does not cite or discuss the California case.

56. The facts of the California case were duplicated in In re Meisel, $159 \mathrm{~F}$. Supp. 879 (D. Md. 1958). Chief Judge Thomsen reviewed the Ninth Circuit's California decision at length, contrasting it with the Third Circuit's decision in In re Quaker City Uniform Co., 238 F.2d 155 (3d Cir. 1956), cert. denied, 352 U.S. 1030 (1957). See text accompanying notes 62-73 infra. In Meisel (as in California) the federal liens exceeded the fund, so that the actual distribution would be the same (administrative expenses first, federal lien second, with no balance remaining for the state lien) whether the theory of the California case or that of the Quaker City case was adopted. Judge Thomsen sensibly contented himself with ordering the distribution of the fund, without deciding which of the theories was correct. The Meisel opinion does not cite the Harrell case or discuss the possibility of 
Another recent section 67 (c) (1) case, which also arrives at the subordination rule of distribution, is In the Matter of American Zyloptic Co.57 The competing claims were a chattel mortgage (in the amount of $\$ 5,000$ ) entitled to priority over a federal tax lien (in the amount of approximately $\$ 6,000$ ), which was, by section 67 (c) (1) subordinated to administration expenses and wage claims (in an amount in excess of $\$ 2,000$ ). The fund to be distributed was approximately $\$ 13,000$, so that all the claims could not be paid in full. The referee, following the decision of the Third Circuit in In re Quaker City Uniform, ${ }^{58}$ ordered distribution first, to the administration expenses and wage claims; second, to the federal tax lien; last, to the chattel mortgage. Judge Byers, finding no Second Circuit decision in point and declining, with respect, to follow the Third Circuit, ordered the following distribution: 1) Set aside from the fund $\$ 6,000$ (the amount of the federal tax lien) and pay from that amount first the administration expenses, then the wage claims, balance, if any, to go to the federal lien; 2) Pay the chattel mortgage from the $\$ 7,000$ balance remaining after the setting aside of the amount of the tax lien (this pays the mortgage in full and still leaves $\$ 2,000$ ) ; 3) Apply the remainder of $\$ 2,000$ first to the administration expenses and wage claims, then to the federal lien. This is the standard subordination distribution, with the federal lien as $A$, the mortgage as $B$ and the section 64 priority claims as $C$. Judge Byers thus applies exactly the same theory that the Ninth Circuit had adopted in the California case: in Zyloptic, however, the federal lien was smaller than the fund, so that Judge Byers had to provide for successive distributions after the initial setting aside of $A$ 's claim, which he did in the normal fashion. Curiously, Judge Byers, after reviewing the California case, concluded that it was distinguishable from his own case for the reason that the $B$ claim in California was a state lien not subject to the section 67 (c) (1) subordination provision while the $B$ claim in Zyloptic was a mortgage. (Judge Byers also referred to the Harrell case but dismissed it as being of "no assistance." If he meant that the Harrell rule was wrong and that he would not follow it, the dismissal is understandable. If he meant that the Harrell case was not in point, it is hard to follow his reasoning.) Judge Byers attributed the distribution which he ordered to "the suggestion found at page 298 of Vol. 4 of Collier, 14th ed." :60 at that point the editor of Collier's merely states what we have called the subordination rule as one of several possible solutions which have been, or could be, applied to the section 67 (c) (1) circularity. ${ }^{01}$

distributing the fund according to the Harrell rule. The federal lien in Meisel (as in Califorria) was in the pusition of the mortgages in Harrell: under Harrell, therefore, the federal lien in $M$ eisel would have been first paid, which would have exhausted the fund.

57. 181 F. Supp. 77 (E.D.N.Y. 1960).

58. 238 F.2d 155 (3d Cir. 1956), cert. denied, 352 U.S. 1030 (1957).

59. American Zyloptic Co., 181 F. Supp. 77, 81 (E.D.N.Y. 1960).

60. Ibid.

61. The only case authority which the 14th edition of Collzer's, as revised in 1954, cites for the distribution is In re Empire Granite Co., 42 F. Supp. 450 (M.D. Ga. 1942). 
We noted earlier that in the non-bankruptcy cases which have applied the rule to the trio of local tax (or mechanic's) lien, mortgage and federal lien, the mortgage has been $A$ (the subordinator), the federal lien $B$, and the local or mechanic's lien $C$ (beneficiary of the subordination). In Zyloptic, as in the other section 67 (c) (1) bankruptcy cases which have applied the rule, the federal lien becomes $A$, the mortgage ( $Z y$ loptic) or unsubordinated lien (California) $B$, and the section 64 priorities $C$.

Except for the Harrell case, whose status even in the Fifth Circuit is doubtful, the only dissent from the subordination rule in recent years has been the Third Circuit case of In re Quaker City Uniform Co., ${ }^{62}$ a bankruptcy case which involved the section 67 (c) (1) circularity. In Quaker City there was a chattel mortgage ${ }^{63}$ (in the amount of approximately $\$ 6,000$ ), which by state law was subordinate to the lien of a distraining landlord (for a rent claim of approximately $\$ 3,500)$, which was in turn subordinated by section 67 (c)(1) to administration expenses and wage claims (which totaled about $\$ 12,000$ ). The fund available for distribution was just short of $\$ 10,000$. The possible range of confusion in the section 67 (c) (1) cases is well illustrated by the three distributions which were ordered in Quaker City. The referee, following (or at any rate applying) the Harrell rule, concluded that the mortgage came first, the section 64 priorities second, and the landlord last. (This paid the mortgage and administration expenses in full with about $\$ 3,000$ left for the wage claims. The landlord got nothing.) The District Court applied the subordination rule: set aside the amount of the mortgage and from this pay first the landlord $(C)$ and then the mortgagee $(A)$; pay the balance remaining to the section 64 priorities. (This paid the landlord in full, gave the mortgagee $\$ 2,500$ and the priority claims $\$ 4,000$.) The Circuit Court held that the proper order of distribution was: first, the priority claims; second, the landlord; third, the mortgage. (This gave the entire fund to the priority claims; neither the landlord nor the mortgagee received anything.)

In its first opinion, which was subsequently withdrawn and is not officially reported, ${ }^{64}$ the Circuit Court had awarded the fund to the priority claims on the theory that both the mortgage and the landlord's lien were "statutory liens" under section $67(\mathrm{~b})$ and hence that both were subordinated to the priorities under section 67 (c)(1). After anguished outcry from the Pennsylvania bar, the Court withdrew the heretical opinion which stigmatized all mortgages as statutory liens and prepared a second opinion which, on different theory, succeeded in distributing the fund the same way (i.e., the priority claims take all). In arriving at this conclusion, Judge Staley first disposed of the Harrell case, which supported the referee's position: Harrell, he said,

62. 238 F.2d 155 (3d Cir. 1956). The Circuit reaffirmed the Quaker City doctrine in In re Einhorn Bros., Inc., 272 F.2d 434 (3d Cir. 1959).

63. In fact there were two mortgages, which aggregated $\$ 6,000$; for simplicity we will treat them as one.

64. See 2 Bankr. L. Rep. $\int 58778$ (3d Cir. 1956) ; Comment, 66 Y ALE L.J. 784, 792 n.43 (1957). 
which promoted a mortgage over a state lien which, except for bankruptcy, would by state law have had priority over the mortgage, "contains the undesirable feature of needlessly upsetting state lien priority rules." reason," he added, the Ninth Circuit had rejected Harrell in the California case. With respect to the California case (which the District Court had in effect followed $)^{66}$ Judge Staley's opinion becomes curious in the extreme. The District Court's version of the California (subordination) rule had been to pay the landlord $(C) \$ 3,500$, the mortgagee $(A) \$ 2,500$ and the priority claims $(B) \$ 4,000$. After stating this, Judge Staley adds, bewilderingly, that the District Court's "sole concern was apparently to insure payment of administrative expenses and small wage claims." 67 From that point, Judge Staley's opinion seems to assume that the Califormia case required, and that the District Court in Quaker City had ordered, a distribution in which the landlord was $A$, the priority claims $C$, and the mortgage $B$. (This, which was not, according to Judge Staley's own earlier statement, what the District Court had done, would have paid the mortgagee in full $(\$ 6,000)$ and given the balance $(\$ 4,000)$ to the priority claims ${ }^{68}$ - the same distribution which the referee had ordered, albeit arrived at by a different theoretical route.) This distribution, which the District Court had not-repeat, not-ordered, was wrong said Judge Staley, because the landlord's lien, superior by state law, "will be defeated to the extent of the administrative expenses and wage claims" (i.e., has the same defect as the Harrell case and the referee's distribution). Thus the District Judge, the only one who had devised a solution which paid the landlord, was reproved for not having sufficiently respected the landlord's "superior lien." It should be added that Judge Staley's version of the subordination rule, as applied to the Quaker City facts, is neither impossible nor lacking in support: the learned author of a note on Quaker City in the Yale Law Journal concluded that the solution, wrongly attributed to the District Court by Judge Staley, was in fact the correct solution. ${ }^{70}$ Since the Circuit Court's solution gives the entire fund to the priority claims, it might be thought that that solution, too, insufficiently respected the landlord's claim and the state system of priorities: to this accusation Judge Staley's reply is that the Court's solution does preserve the state priorities, in that the landlord is ranked, theoretically, above the mortgagee. The landlord receives nothing on distribution, but that is merely the unfortunate result of the fact that the

65. In re Quaker City Uniform Co., 238 F.2d 155, 159 (3d Cir. 1957).

66. Chief Judge Kirkpatrick's opinion for the District Court, Quaker City Uniform Co., 134 F. Supp. 596 (E.D. Pa. 1955), does not cite the Califortia case or any of the other circularity cases arising under $\$ 67$ (c) (1) or otherwise.

67. $238 \mathrm{~F} .2 \mathrm{~d}$ at 158.

68. I.e., set aside the landlord's ( $A$ 's) claim, $\$ 3500$; this goes to the priority claims $(C)$. Pay the mortgage $(B)$ from the balance. Since the balance is $\$ 6500$ the mortgage $(\$ 6,000)$ is paid in full. The remainder of $\$ 500$ goes once again to $C$, the priority claims.

69. 238 F.2d at 159.

70. Comment, 66 YaLE L.J. 784, 793-94 (1957). 
priority claims exceeded the fund. The affirmative argument in support of the Court's solution [(1) priority claims; (2) landlord; (3) mortgage] is briefly put:

In view of the fact that Congressional intent was to favor expenses of administration and wage claims while leaving state priorities unaffected, we hold that the lien of the chattel mortgage, inferior under state law, is by necessary implication postponed by Section 67, sub. C, to a position behind the subordinated landlord's lien. ${ }^{71}$

Quaker City thus rests on what might be called the theory of "necessary implication"72 from the presumed intent which underlies section 67 (c)(1). It is an exercise in statutory construction rather than a contribution to circularity theory. ${ }^{73}$

In the two types of circularity cases which have monopolized litigation since approximately 1940 , distribution according to the subordination rule has been the preferred choice of all the courts, with the exception of the Third Circuit and possibly the Fifth Circuit. Some of the opinions have, to a greater or lesser degree, articulated reasons for choosing the rule; other opinions have not. However, what the courts do in fact, as we have been reminded by high authority, should be accorded great weight. Indeed, apart from Judge Dixon and the commentators who have sought to refine his junior lien theory, the subordination rule appears to be the majority rule in academic circles as it is in judicial circles. If the type of circularity case which results from the failure of one of the parties to make a required filing reappears (and there is no reason why it should not), the subordination rule would appear to be as

71. 238 F.2d at 159-60. Judge Staley cites as authority 4 CollIER, BankRUPTCY 291, 297 n.41 (14th ed. 1959). Viewed as a whole, the discussion in Collier is an evenhanded presentation of a variety of possible solutions to the $\$ 67$ (c) (1) circularity problem, which concludes with the suggestion that amendment of $\$ 67$ (c) (1) would be "desirable." The only case cited by ColLIer in the passage to which Judge Staley refers is In re Michael's Cafeteria, Inc., 49 F. Supp. 657 (D. La. 1943), on rehearing, 52 F. Supp. 799, of which the editor remarks that the solution adopted by Judge Staley in Quaker City "presumably underlies" the case. The author of the Yale comment doubts that the Michael's Cafeteria case goes even that far. 66 YALE L.J. 784, 792 n.44 (1957).

72. Compare with Judge Staley's "necessary implication" the Chancellor's remark in the Chic-Mint case, stpra note 41 , that "it must necessarily follow that . . " and Justice Schwartz's remark in the Samms case, supra note 49, that the result was "inevitable."

73. In In $r e$ Einhorn Bros., Inc., 272 F.2d 434 (3d Cir. 1959), the Circuit reconsidered the $\$ 67(\mathrm{c})(1)$ circularity problem in a case which differed, in substance, from Quaker City only in that the interest not subject to subordination under $\$ 67$ (c)(1) was a security interest under Article 9 of the Uniform Commercial Code instead of a pre-Code chattel mortgage. Judge Wood remarked: "The Bank did not seriously urge this Court to overrule its decision in Quaker City," id. at 438. Most of Judge Wood's opinion refutes attempted distinctions which the Bank had urged on the court in an effort to escape from coming in last under Quaker City. The Bank came in last in Einhorn.

In In re George Townsend Co., 180 F. Supp. 625 (E.D. Pa. 1957) the facts of the Quaker City case were duplicated, except that the landlord had not actually distrained for the rent before the petition in bankruptcy was filed. It was held that the failure to distrain made Quaker City (and $\$ 67(\mathrm{c})(1)$ ) inapplicable. 
appropriate in such cases as in the types of cases with which the courts have been dealing: indeed many of the older cases and law review articles apply or advocate the subordination rule in failure-to-file circularity cases. ${ }^{\mathbf{7 4}}$

The results which the rule produces in actual distributions may appear to be whimsical and arbitrary. $B$, who gets nothing when $A$ 's claim equals or exceeds the fund, is progressively better off as $A$ 's claim decreases (since $B$ takes the balance). $C$ is in the reverse position: the larger $A$ 's claim (which $C$ takes), the better $C$ fares. Whether or not $A$ takes anything depends on the size of $C$ 's claim: whenever it equals or exceeds his own, $A$ takes nothing until $B$ and $C$ have been paid in full; the smaller $C$ 's claim, the more $A$ gets. All these results might be described as purely accidental, since in a true circularity case none of the parties figures out his position in advance with reference to the other competing claims, which are either unknowable or unknown to him until it is too late for him to get out. On the other hand, it can be fairly said that neither Judge Dixon's formula, nor the more sophisticated formulae which have been derived from it, produce results which are any less accidental or more clearly equitable; nor does the simpler expedient of breaking the circle at some point (à la Quaker City, Harrell, and Chic-Mint) seem to produce results which are more in accord with either natural justice or the reasonable expectations of the parties.

In Quaker City, of course, the Third Circuit based its decision neither on natural justice nor on reasonable expectation but on a "necessary implication" from section 67 (c) (1) of the Bankruptcy Act. It would, of course, be entirely within the congressional power to order the circle broken as the Third Circuit did in Quaker City or to solve the circularity in any way it wanted (or to redraft section 67 (c) (1) so as to avoid the circularity). ${ }^{75}$ As to the Third Circuit's "necessary implication," no other court which has examined section 67 (c) (1), before or after Quaker City, has found it. And, with the possible exception of the Fifth Circuit, in which the sequence of the Harrell and $T u b b s$ cases creates ambiguity, no court has suggested that, as a matter of statutory construction, section 67 (c) (1) requires a solution of the circularity problem different from the solution which the court would apply in other types of circularity cases.

The principal confusion which has arisen in applying the subordination rule to true circularity cases has been the allocation of claimants to the $A, B$, and $C$ slots. In failure-to-file cases the allocation presents no particular difficulty. The non-filer is the obvious choice for $A$ (the subordinator) and the party

74. As, e.g., the twelve judges of the New Jersey Court (Dixon, J., dissenting) did in Hoag v. Sayre, 33 N.J. Eq. 552 (1881). For a similar approach, see Dyson v. Simmons, 48 Md. 207 (1877) ; Miller v. Stoddard, 54 Minn. 486, 56 N.W. 131 (1893) ; Neff's Adm'r v. Newman, 150 Va. 203,192 S.E. 389 (1928).

75. The most recent congressional attempt to remedy the situation, H.R. REP. No. 7242, 86th Cong., 1st Sess. (1960), was vetoed by the President because of his belief that the amendment would unduly interfere with the collection of federal tax revenues. 106 Cong. Rec. 19168 (daily ed., Sept. 1, 1960) (Veto message of President Eisenhower). 
who has taken without knowledge for $C$ (beneficiary of the subordination). But in the no-fault cases, arising from the conflict of inconsistent federal and state priority systems, the allocation becomes tricky: In the non-bankruptcy cases, which do not involve section 67 (c) (1), there is a federal lien or claim in competition with two non-federal interests, which depend for their validity and rank on state law: the trouble comes from the fact that, by Supreme Court doctrine, the federal claim is superior to the interest which is senior by state law but inferior to the interest which is junior by state law. In this situation the courts which have applied the subordination rule have without exception called the federal claim $B$, the senior interest by state law $C$, the junior interest $A$ : that is, in the typical case of a mechanic's lien, a mortgage (or other security interest), and a federal tax lien, the court orders the amount of the mortgage $(A)$ to be set aside, the mechanic's lien $(C)$ to be paid from this amount, and the federal lien $(B)$ to be paid from the balance remaining after the setting aside. ${ }^{76}$ In the bankruptcy cases, the competing claims are 1) administration expenses and wage claims entitled to a section 64 priority; 2) a statutory lien subordinated to the section 64 priorities by section $67(\mathrm{c})(1)$; 3) a security interest or a lien not subject to the section 67 (c) (1) subordination. With one exception, the courts which have adopted the subordination rule have done so by calling the interest not subject to the section 67 (c) (1) subordination $B$, the subordinated lien $A$ and the section 64 priorities $C$ : thus the amount of the subordinated statutory lien is set aside, the section 64 priorities paid from that, and the unsubordinated lien (typically, but not necessarily, a mortgage) paid from the balance. The one exception is the District Court's order in the Quaker City case: the District Judge called the unsubordinated lien (which happened to be a mortgage) $A$, the subordinated lien (senior to the mortgage by state law) $C$, and the section 64 priorities $B$. That is, the District Judge chose the two secured claims (mortgage and landlord's lien) as $A$ and $C$, and ranked them according to their state law priorities, giving to the section 64 priorities the balance of the fund left after the secured claim junior by state law had been set aside. Everyone else has taken as $A$ and $C$ the two claims which are specifically subject to the Bankruptcy Act provisions (i.e., the subordinated lien and the section 64 priorities) and ranked them according to the Bankruptcy Act hierarchy; that gives to the mortgage or lien not subordinated by section 67 (c) (1) the balance of the fund left after the claim junior by bankruptcy law (i.e., the subordinated lien) has been set aside. Logic may not point a compelling finger in either direction: the present writer is inclined to align himself with the District Judge in Quaker City on the perhaps not too persuasive ground that one rule

76. See Exchange Bank \& Trust Co. v. Tubbs Mfg. Co., 246 F.2d 141 (5th Cir. 1957), ccrt. denicd, 355 U.S. 868 (1957) ; United States v. Lord, 155 F. Supp. 105 (D. N.H. 1957) ; Brown v. General Laundry Serv., 19 Conn. Supp. 335, 113 A.2d 601 (1955) ; Samms v. Chicago Title \& Trust Co., 349 I11. App. 413, 111 N.E.2d 172 (1953); Manchester Federal Sav. \& Loan Ass'n v. Emery-Waterhouse Co., 102 N.H. 233, 153 A.2d 918 (1959); Southern Ohio Sav. Bank \& Trust Co. v. Bolce, 165 Ohio St. 201, 135 N.E.2d 382 (1956). 
is better than two, that there is no reason for differentiating the section 67 (c) (1) cases from the non-bankruptcy cases, and that picking the two secured claims as $A$ and $C$ and ranking them according to their state law priority is in effect what has been done by all courts in the non-bankruptcy cases.

Experience, as Justice Holmes might have told us, solves more problems than logic. With respect to circular priorities, the logicians had their turns at bat but, if we go by the case-law boxscore, struck out. In the cases decided since 1950, the courts, however motivated, have been deciding circularity cases with an impressive record of consistency which has been marred only by the Third Circuit's fall from grace in Quaker City. Textbook and law review discussions of the circularity problem have usually emphasized the extraordinary number of "solutions" which have been proposed and leave the reader with the impression that the courts have picked now one, now another, in a completely random fashion. ${ }^{77}$ According to the recent returns, however, there is only one solution which is regularly followed, and that is distribution in the same way that would be ordered if the circularity had arisen from a contractual subordination. Apart from the Third Circuit's deviation, the only remaining area of confusion lies in the allocation of claims to the subordination pattern in the section 67 (c) (1) cases. As is not infrequently the case, the courts have been doing a good deal better than their critics.

77. See, e.g., Osborne, Mortgages $\S 209$ (1951); Note, 38 Colum. L. Rev. 1267 (1938). 